\title{
Genetic Basis for Varied Levels of Injury to Sweet Corn Hybrids from Three Cytochrome P450-metabolized Herbicides
}

\author{
Jerald K. Pataky ${ }^{1}$ and Michael D. Meyer \\ Department of Crop Sciences, University of Illinois, 1102 South Goodwin Avenue, Urbana, IL 61801
}

Joseph D. Bollman and Chris M. Boerboom

Department of Agronomy, University of Wisconsin, Madison, WI 53706

\author{
Martin M. Williams II \\ U.S. Department of Agriculture-Agricultural Research Service, Invasive Weed Management \\ Research, University of Illinois, Urbana, IL 61801
}

\begin{abstract}
AdDitional INDEX words. benl gene, foramsulfuron, herbicide selectivity, herbicide sensitivity, herbicide tolerance, mesotrione, nicosulfuron, $n s f 1$ gene, Zea mays

Abstract. Some sweet corn (Zea mays L.) hybrids and inbreds can be severely injured or killed after postemergence applications of certain P450-metabolized herbicides. Consequently, existing hybrids are regularly evaluated for tolerance to new herbicides, and new hybrids are evaluated for tolerance to existing herbicides. In 2005 and 2006 , the University of Wisconsin Cooperative Extension Service coordinated 12 trials in six states in which a total of 149 sweet corn hybrids were evaluated for tolerance to three cytochrome P450-metabolized herbicides: nicosulfuron, foramsulfuron, and mesotrione. Hybrid responses differed substantially within and among locations. The objective of this study was to determine if alleles affecting herbicide sensitivity (e.g., cytochrome $\mathbf{P 4 5 0}$ alleles) were associated with differences in levels of injury to sweet corn hybrids in these trials. Based on responses of $F_{2}$ progeny to nicosulfuron, foramsulfuron, and mesotrione, 95 hybrids were classified as homozygous for alleles conditioning herbicide tolerance; 47 hybrids were classified as heterozygous with one allele each conditioning tolerance and sensitivity; and two hybrids were classified as homozygous for alleles conditioning sensitivity. When trial mean levels of injury after applications of mesotrione, nicosulfuron, and foramsulfuron in the herbicide trials were above $1 \%$, $4 \%$, and $5 \%$, respectively, the response of the three genotypic classes of hybrids followed a consistent pattern. Homozygous-sensitive hybrids were injured most severely and often were killed by the two acetolactate synththaseinhibiting herbicides, nicosulfuron and foramsulfuron. Heterozygous hybrids had an intermediate response to all three herbicides that was more similar to homozygous-tolerant hybrids than homozygous-sensitive hybrids; however, injury to heterozygous hybrids was 1.5 to 2.3 times greater and significantly $(P<0.05)$ different from homozygoustolerant hybrids based on $t$ tests of group means and comparisons of predicted values from regressions of genotypic means on trial means. Based on responses of the 149 hybrids in this trial, the potential for and level of crop injury from use of nicosulfuron, mesotrione, and foramsulfuron on any specific sweet corn hybrid is conditioned largely by alleles at a single locus.
\end{abstract}

Cytochrome P450 enzymes in corn play an integral role in phase I metabolism of herbicides in at least six chemical families (Barrett 1995, 2000). Some sweet corn hybrids and inbreds can be injured or killed after postemergence applica-

Received for publication 5 Nov. 2007. Accepted for publication 7 Mar. 2008. A portion of this research was supported by a University of Illinois, College of ACES Undergraduate Research Fellowship.

We appreciate the cooperation of various seed companies that contributed seeds of hybrids and/or planted a location of the herbicide trials, including Crookham Co., Caldwell, ID; Harris Moran Seed Co., Modesto, CA; Mesa Maize, Olathe, CO; Syngenta Seeds, Inc. Rogers Brands, Boise, ID; Seminis Inc., Oxnard, CA; and Snowy River Seeds, Orbost, Australia. Public sector cooperators who planted or evaluated trials include: Don Morishita, University of Idaho, Twin Falls; Mark VanGessel, University of Delaware, Georgetown; Robin Bellinder, Cornell University, Ithaca, NY; Wayne Cooley, Colorado State University, Delta; and Roger Becker, University of Minnesota, St. Paul. We thank Bryan Warsaw and Jim Moody for their technical assistance.

Mention of a trademark, proprietary product, or vendor does not constitute a guarantee or warranty of the product by the U.S. Department of Agriculture and does not imply its approval to the exclusion of other products or vendors that also may be suitable.

${ }^{1}$ Corresponding author. E-mail: j-pataky@uiuc.edu. tions of certain P450-metabolized herbicides, including those that inhibit acetolactate synthase (ALS) or 4-hydroxyphenylpyruvate-dioxygenase (HPPD) such as nicosulfuron, foramsulfuron, and mesotrione (Diebold et al., 2003; Masiunas et al., 2004; Morton and Harvey, 1992; O'Sullivan et al., 2002; Robinson et al., 1993; Stall and Bewick, 1992; Williams et al., 2005). The adoption and use of new postemergence herbicides in sweet corn and the use of existing herbicides on new sweet corn hybrids are limited by the potential for crop injury. A better understanding of the basis for variation among sweet corn hybrid response to P450-metabolized herbicides would allow for more informed decisions about the potential for crop injury when these chemicals are used.

Varied responses to P450-metabolized herbicides may be the result of dissimilar rates of metabolism among sweet corn hybrids that differ for alleles that regulate cytochrome P450 monooxygenases. Differences in metabolism rates of nicosulfuron appear to be responsible for different responses of a tolerant sweet corn hybrid, 'Landmark', and a sensitive sweet corn hybrid, 'Merit' (Burton et al., 1994). Sensitivity to 
nicosulfuron is conditioned by a single recessive gene designated as either $n s f 1$ or benl (Barrett et al., 1997; Green and Ulrich, 1993; Kang, 1993). The dominant allele, Nsf1, from a nicosulfuron-tolerant field corn inbred line, B73, was recently sequenced after being located on chromosome 5S. Nsfl was the second locus among a cluster of four closely linked genes with homologies to cytochrome P450 genes (i.e., CYP genes) (Williams et al., 2006). Nicosulfuron-sensitive field corn inbred lines, GA209 and W703A, from which the ben 1 and $n s f 1$ genes were originally identified (Fleming et al., 1988; Kang, 1993), contained the same 392-base pair insertion in the Nsfl gene sequence relative to nicosulfuron-tolerant lines. Hence, $n s f 1$ and ben 1 appear to be the same insertion mutation of a CYP gene.

Some sweet corn hybrids and inbreds are sensitive to multiple P450-metabolized herbicides, including nicosulfuron, foramsulfuron, and mesotrione (Nordby, 2008; Williams et al., 2005). Sensitivity to these and other P450-metabolized herbicides in the sweet corn inbred $\mathrm{Cr} 1$ is inherited as a single recessive gene (Pataky et al., 2006) or a group of closely linked genes that appear to be allelic with or very closely linked to the nsfl/ben1 gene (Nordby et al., 2008). This gene or group of genes appears to be widely prevalent in commercially available sweet corn hybrids and their inbred parents (Pataky et al., unpublished data). Biomass of sweet corn hybrids nearly isogenic for CYP alleles at Nsfl or a closely linked locus differed after application of mesotrione in dose-response studies (Volenberg et al., 2006). Biomass of the heterozygous hybrid was intermediate to that of near isogenic homozygoussensitive and homozygous-tolerant hybrids.

Because of potential injury from postemergence herbicides, existing sweet corn hybrids are regularly evaluated for response to new herbicides, and new hybrids are evaluated for response to existing herbicides to identify sensitive hybrids (e.g., Bollman et al., 2006; Diebold et al., 2003; Edenfield and Allen, 2005; Morton and Harvey, 1992; O'Sullivan et al., 2002; Williams and Pataky, 2008; Williams et al., 2005). In 2005 and 2006, the University of Wisconsin Cooperative Extension Service coordinated a sweet corn hybrid-herbicide trial in which a total of 149 hybrids were evaluated for tolerance to nicosulfuron, foramsulfuron, and mesotrione in 12 trials in Wisconsin, Minnesota, New York, Delaware, Colorado, and Idaho (Bollman et al., 2005). Responses of hybrids differed substantially within and among locations leading to our hypothesis that variation in levels of injury was associated with the presence in some hybrids of one or two mutant CYP alleles (e.g., the $n s f 1 /$ ben 1 allele).

The objective of this study was to determine if alleles affecting herbicide tolerance and sensitivity (e.g., CYP alleles) were associated with differences in levels of injury to sweet corn hybrids in herbicide trials coordinated by the University of Wisconsin in 2005 and 2006.

\section{Materials and Methods}

Herbicide trials. Responses of 149 commercial sweet corn hybrids to postemergence applications of nicosulfuron, foramsulfuron, and mesotrione were evaluated in 2005 and 2006 in a total of 12 field experiments at nine locations, including Olathe, CO; Georgetown, DE; Caldwell, ID; Nampa, ID; Stanton, MN; LeRoy, NY; DeForest, WI; Plainfield, WI; and Sun Prairie, WI. The hybrids represent diverse genetic backgrounds from six different commercial sweet corn breeding programs and include sugary, sugary, enhancer, and shrunken-2 endosperm mutants. These hybrids are grown commercially for fresh market and processing throughout North America and the world. Trials in 2005 and 2006 included 114 and 81 sweet corn hybrids, respectively. Forty-five hybrids were common to trials in both years. Field sites were prepared using conventional production practices. Preemergence herbicides applied after planting were selected to control earlyseason weeds based on site-specific needs. Each trial included six duplicate ranges of sweet corn hybrids planted in 6-m long rows spaced $76 \mathrm{~cm}$ apart. Planting density was 40 seeds per row. Within each pair of ranges, one was treated with a postemergence herbicide and one was a nontreated control. Thus, each trial included one replicate of hybrids for each of three pairs of herbicide-treated and nontreated ranges. Randomization of hybrids differed in each of seven trials (i.e., locations) in 2005 and five trials (i.e., locations) in 2006.

Herbicide treatments were applied at the V3 to V4 growth stage (Ritchie et al., 1997) at twice the normal use or anticipated use rates to maximize differences among tolerant and sensitive hybrids. Nicosulfuron was applied at $70 \mathrm{~g} \cdot \mathrm{ha}^{-1}$ a.i. plus $1 \% \mathrm{v} / \mathrm{v}$ petroleum oil concentrate and $2.2 \mathrm{~kg} \cdot \mathrm{ha}^{-1}$ ammonium sulfate. Foramsulfuron was applied at $74 \mathrm{~g} \cdot \mathrm{ha}^{-1}$ a.i. plus the safener isoxadifen-ethyl at $74 \mathrm{~g} \cdot \mathrm{ha}^{-1}$ a.i., $1.8 \mathrm{~L} \cdot \mathrm{ha}^{-1}$ methylated seed oil, and $2.2 \mathrm{~kg} \cdot \mathrm{ha}^{-1}$ ammonium sulfate. Safeners such as isoxadifenethyl enhance the activity of degradative enzymes such as cytochrome $\mathrm{P} 450$ monooxygenases, thus protecting plants from injurious herbicides such as the sulfonylureas (Hatzios, 1997). Mesotrione was applied at $210 \mathrm{~g} \cdot \mathrm{ha}^{-1}$ a.i. plus $1 \% \mathrm{v} / \mathrm{v}$ petroleum oil concentrate. All three herbicides were applied in $190 \mathrm{~L} \cdot \mathrm{ha}^{-1}$ spray volume.

Sweet corn injury was evaluated 7 and $14 \mathrm{~d}$ after application of herbicide treatments. Injury from nicosulfuron and foramsulfuron was visually assessed as percent stunting $(0 \%$ to $100 \%)$. Injury from mesotrione was assessed visually as the percentage of the total leaf area bleached or chlorotic $(0 \%$ to $100 \%)$.

Greenhouse ANd field eVAluations of $F_{2}$ Progeny. Sweet corn hybrids included in the 2005 and 2006 herbicide trials were grown in 2006 at the University of Illinois Vegetable Crops Farm, Champaign. Each hybrid was grown in a single, $3-\mathrm{m}$ long row of 15 plants. Seeds of $\mathrm{F}_{2}$ progeny were produced for 144 of the 149 hybrids by self-pollinating five to 10 plants per row.

Phenotypic responses of $\mathrm{F}_{2}$ progeny to nicosulfuron, foramsulfuron, and mesotrione were assayed to determine if hybrids were homozygous or heterozygous for a gene(s)conditioning response to these herbicides. $F_{2}$ progeny of 144 hybrids were assayed for responses to nicosulfuron and foramsulfuron in greenhouse trials at the University of Illinois Plant Care Facility. Responses of $\mathrm{F}_{2}$ progeny to mesotrione were assayed in field trials in 2007 at the University of Illinois Crop Sciences Research and Education Center, Champaign.

Greenhouse evaluations of responses of $F_{2}$ progeny to postemergence applications of nicosulfuron and foramsulfuron were adapted from the methods used by Nordby et al. (2008). Seventy-two seeds of $\mathrm{F}_{2}$ progeny of each hybrid were planted in a randomly assigned $30 \times 60 \times 7-\mathrm{cm}$ flat containing a $1: 1$ : 1 mixture of soil, peat, and perlite supplemented with $15 \mathrm{~N}-$ 3.9P-9.7K Osmocote Plus ${ }^{\circledR}$ (Scotts Co., Marysville, OH) slowrelease fertilizer. One flat of an herbicide-sensitive inbred, $\mathrm{Cr} 1$, 
and one flat of an herbicide-tolerant inbred, $\mathrm{Cr} 2$, were included as controls. Herbicides were applied when plants were at the three-leaf stage, $\approx 13 \mathrm{~d}$ after planting. Two flats were sprayed simultaneously in an enclosed spray chamber equipped with an $80^{\circ}$ flat-fan nozzle delivering $187 \mathrm{~L} \cdot \mathrm{ha}^{-1}$ of treatment solutions at $207 \mathrm{kPa}$. Nicosulfuron was applied at $35 \mathrm{~g} \cdot \mathrm{ha}^{-1}$ a.i. with $0.25 \% \mathrm{v} / \mathrm{v}$ nonionic surfactant and $2.5 \% \mathrm{v} / \mathrm{v} 28 \%$ urea ammonium nitrate. Foramsulfuron was applied at $40 \mathrm{~g} \cdot \mathrm{ha}^{-1}$ a.i. plus the safener isoxadifen-ethyl at $40 \mathrm{~g} \cdot \mathrm{ha}^{-1}$ a.i. with $1 \% \mathrm{v} / \mathrm{v}$ methylated seed oil and $2.5 \% \mathrm{v} / \mathrm{v} 28 \%$ urea ammonium nitrate.

In the field trial in 2007 , two replicates of $F_{2}$ progeny of each hybrid and the sensitive and tolerant inbreds were planted in single, $3-\mathrm{m}$ long rows with $\approx 25$ plants per row. The experimental design was a randomized complete block. Mesotrione was applied at the V3 to V4 growth stage at $105 \mathrm{~g} \cdot \mathrm{ha}^{-1}$ a.i. plus $1 \% \mathrm{v} / \mathrm{v}$ crop oil concentrate and $2.5 \% \mathrm{v} / \mathrm{v} 28 \%$ urea ammonium nitrate.

Plants were rated visually $\approx 13 \mathrm{~d}$ after nicosulfuron and foramsulfuron were applied and $7 \mathrm{~d}$ after mesotrione was applied. Plants sensitive to nicosulfuron or foramsulfuron usually were dead or nearly dead, although some plants sensitive to foramsulfuron occasionally had malformed leaves and symptoms similar to injury caused by a plant growth regulator. Leaf tissue in whorls of plants sensitive to mesotrione was severely chlorotic or "bleached." The number of sensitive and tolerant $\mathrm{F}_{2}$ plants was counted. Hybrids with all $\mathrm{F}_{2}$ progeny killed or severely injured were classified as sensitive and homozygous for an allele-conditioning herbicide sensitivity. Hybrids with uninjured $\mathrm{F}_{2}$ progeny were classified as tolerant and homozygous for an allele conditioning herbicide tolerance. Hybrids with sensitive and tolerant $\mathrm{F}_{2}$ progeny were tested by $\chi^{2}$ analysis for goodness of fit for segregation of tolerant:sensitive $F_{2}$ progeny in a ratio of $3: 1$, which would be expected if a single dominant gene conditioned a tolerant phenotypic response (e.g., the $N s f 1$ allele). If segregation of $\mathrm{F}_{2}$ progeny fit a $3: 1$ ratio $(P>0.01)$, hybrids were classified as heterozygous for alleles conditioning tolerance and sensitivity. If more than $10 \%$ of the $\mathrm{F}_{2}$ progeny were sensitive but the ratio of tolerant:sensitive plants did not fit a $3: 1$ ratio $(0.01<P<$ $0.001)$, hybrids were still classified as heterozygous. When fewer than $5 \%$ of the $\mathrm{F}_{2}$ progeny were sensitive to the three herbicides and segregation did not fit a $3: 1$ ratio $(P<0.001)$, hybrids were classified as tolerant.

COMPARISON OF FIELD RESPONSES OF TOLERANT, SENSITIVE, AND HETEROZYGOUS HYBRIDS. Responses of individual hybrids were not compared within trials because each of the 12 trials included only one replicate of hybrids treated with each of the three herbicides. However, in each trial, an adequate number of hybrids were classified as homozygous-tolerant or heterozygous to allow for statistical comparison of mean injury from each herbicide between the groups of homozygous-tolerant and heterozygous hybrids. Thus, mean levels of injury were compared by $t$ tests between 74 homozygous-tolerant and 34 heterozygous hybrids in 2005 and between 54 homozygoustolerant and 24 heterozygous hybrids in 2006. Homozygoussensitive hybrids were not included in the statistical analysis because sample size was too small $(n=2$ and 1 in 2005 and 2006, respectively).

Responses to each herbicide also were compared by regression of mean levels of injury of homozygous-tolerant and heterozygous hybrids from each trial against trial mean levels of injury. Injury to heterozygous hybrids was compared as a ratio with injury to homozygous-tolerant hybrids based on predicted values from regression.

\section{Results}

EVALUATIONS OF $F_{2}$ PROGENY AND CLASSIFICATION OF HYBRIDS INTO GENOTYPIC CLASSES. All of the 105 plants of the sensitive inbred, $\mathrm{Cr}$ 1, were killed or severely injured by applications of nicosulfuron, foramsulfuron, or mesotrione. None of the 110 plants of the tolerant inbred, $\mathrm{Cr} 2$, were injured by these herbicides. Two hybrids, 'Merit' and 'EX 08705770', were classified as homozygous-sensitive because all $373 \mathrm{~F}_{2}$ progeny of these hybrids were injured or killed after applications of nicosulfuron, foramsulfuron, or mesotrione. These hybrids are homozygous for an allele that conditions herbicide sensitivity. Ninety-five hybrids were classified as homozygous-tolerant (Table 1) based on responses of their $\mathrm{F}_{2}$ progeny. These hybrids are homozygous for an allele that facilitates metabolism of these herbicides. None of $10,844 \mathrm{~F}_{2}$ progeny of 73 homozygous-tolerant hybrids were injured after applications of nicosulfuron, foramsulfuron, or mesotrione. An additional 22 hybrids were classified as homozygous-tolerant, although less than $1 \%$ (19 of 2534) of the $\mathrm{F}_{2}$ progeny were sensitive to nicosulfuron or foramsulfuron and less than 4\% (117 of 3424) of the $\mathrm{F}_{2}$ progeny were sensitive to all three herbicides. Fortyseven hybrids were classified as heterozygous based on segregation among $F_{2}$ progeny (Table 2). These hybrids have an allele that facilitates herbicide metabolism and an allele that does not. Segregation of $\mathrm{F}_{2}$ progeny from 41 hybrids was not significantly different $(P \geq 0.01)$ from a $3: 1$ ratio of tolerant:sensitive plants (Table 2). The percentage of sensitive $\mathrm{F}_{2}$ progeny ranged from $14 \%$ to $37 \%$ for these hybrids. Six hybrids with $10 \%$ to $16 \%$ sensitive $\mathrm{F}_{2}$ progeny also were classified as heterozygous, although segregation was significantly different $(P<0.01)$ from $3: 1$ as a result of too few sensitive progeny (Table 2 ). Possibly, the herbicide-sensitive inbred parent of these hybrids may be segregating at the Nsf1 locus. This explanation seems more plausible than modifying genes because at least one of these five hybrids is known to segregate for resistant and susceptible responses to maize dwarf mosaic virus (J. K. Pataky, personal observation).

Among the 47 heterozygous hybrids, 10 hybrids had fewer than expected (i.e., $25 \%$ ) sensitive $\mathrm{F}_{2}$ progeny for one of the three herbicides (data not shown). Less than $25 \%$ of the $F_{2}$ progeny of 'Devotion', 'EX 0870 5788', 'GH 2042', 'Hollywood', 'Polaris', and 'Welcome TSW' were sensitive to nicosulfuron. Less than $25 \%$ of the $\mathrm{F}_{2}$ progeny of 'Bold', 'Eliminator', How Sweet It Is', and 'Jubilee' were sensitive to foramsulfuron. Less than $25 \%$ of the $\mathrm{F}_{2}$ progeny of 'Jubilee' were sensitive to mesotrione.

Comparison of FIELd RESPONSES TO NICOSUlFuron. Mean injury (percent stunting) at 7 or $14 \mathrm{~d}$ after application of nicosulfuron ranged from $2 \%$ to $27 \%$ and averaged $7.5 \%$ among the 12 trials (Table 3). Injury ranged from $15 \%$ to $100 \%$ and averaged $75 \%$ for homozygous-sensitive hybrids. Fourteen days after application of nicosulfuron, homozygoussensitive hybrids were stunted $80 \%$ or more in 10 of 12 trials and were killed in five of these trials. Mean injury to heterozygous hybrids ranged from $0 \%$ to $50 \%$ and averaged $10 \%$ among the 12 trials. On average, heterozygous hybrids were stunted $11 \%$ and $10 \%$ at 7 and $14 \mathrm{~d}$ after application of nicosulfuron, respectively. Mean injury to homozygous-tolerant 
Table 1. Sweet corn hybrids classified as homozygous-tolerant for a gene-conditioning herbicide sensitivity based on homogeneous-tolerant responses of $\mathrm{F}_{2}$ progeny to nicosulfuron, foramsulfuron, and mesotrione.

\begin{tabular}{|c|c|c|c|c|c|}
\hline Hybrid cultivar & Source $^{z}$ & Hybrid cultivar & Source & Hybrid cultivar & Source \\
\hline Alexis $^{y}$ & MM & Frosty & $\mathrm{Cr}$ & Nantasket & MM \\
\hline Applause & $\mathrm{Cr}$ & $\mathrm{GH} 2171^{\mathrm{y}}$ & Rog & Obsession & Sem \\
\hline Bodacious & $\mathrm{Cr}$ & GSS $1303^{y}$ & $\operatorname{Rog}$ & Passion & Sem \\
\hline Bon Appetit TSW & MM & GSS $1477^{y}$ & Rog & Polka & $\mathrm{Cr}$ \\
\hline Bon Jour TSW & MM & GSS 2008 & Rog & Prelude & $\mathrm{SnRv}$ \\
\hline BSS 3495 & Rog & GSS 6564 & Rog & Protégé & $\operatorname{Rog}$ \\
\hline Cameo $^{\mathrm{y}}$ & $\mathrm{Cr}$ & Harvest Gold & Sem & Providence & Rog \\
\hline Captivate & $\mathrm{Cr}$ & HB 1920 OJ & $\mathrm{SnRv}$ & Reflection & $\mathrm{HM}$ \\
\hline Cascade & $\mathrm{Cr}$ & HB $2162 \mathrm{OL}^{\mathrm{y}}$ & $\mathrm{SnRv}$ & Renaissance & HM \\
\hline Cavalry & HM & HМ 2390 & $\mathrm{HM}$ & Revelation & HM \\
\hline Challenger & Sem & HMX 4387WS & $\mathrm{HM}$ & Rising Sun & $\mathrm{SnRv}$ \\
\hline Colonial & $\mathrm{Cr}$ & HY 0579 OK & $\mathrm{SnRv}$ & Sugar Buns & $\mathrm{Cr}$ \\
\hline CSEYP1-3 & $\mathrm{Cr}$ & HY 17900L & $\mathrm{SnRv}$ & Sugar Pearl TSW & MM \\
\hline CSHYP2-57 & $\mathrm{Cr}$ & Ice Queen & HM & Surpass & $\mathrm{Cr}$ \\
\hline CSUYP2-28 & $\mathrm{Cr}$ & Incredible ${ }^{y}$ & $\mathrm{Cr}$ & Temptation & Sem \\
\hline Dasher & $\mathrm{Cr}$ & Kristine $^{\mathrm{y}}$ & $\mathrm{Cr}$ & Trinity & $\mathrm{Cr}$ \\
\hline Double Up & Rog & Lancaster $^{\mathrm{y}}$ & $\mathrm{SnRv}$ & Tuxedo & MM \\
\hline Early Gold ${ }^{y}$ & $\mathrm{HM}$ & Lancelot $^{\mathrm{y}}$ & MM & UY 0607 OJ & $\mathrm{SnRv}$ \\
\hline Enterprise & $\mathrm{SnRv}$ & Legacy & MM & UY 0712 OJ & $\mathrm{SnRv}$ \\
\hline Equinox & $\mathrm{Cr}$ & Luscious TSW & MM & UY $1953 \mathrm{OK}$ & SnRv \\
\hline Everest $^{\mathrm{y}}$ & $\mathrm{SnRv}$ & Maestro $^{\mathrm{y}}$ & $\mathrm{Cr}$ & Valor & $\mathrm{Cr}$ \\
\hline EX $08705353^{y}$ & Sem & Marvel & $\mathrm{Cr}$ & Venus & $\mathrm{Cr}$ \\
\hline
\end{tabular}

$\overline{{ }^{z} \mathrm{Cr}}=$ Crookham Co., Caldwell, ID; HM = Harris Moran Seed Co., Modesto, CA; MM = Mesa Maize, Olathe, CO; Rog = Syngenta Seeds Inc., Rogers Brands, Boise, ID; Sem = Seminis Inc., Oxnard, CA; SnRv = Snowy River Seeds, Orbost, Australia.

${ }^{y}$ Hybrids classified as tolerant with less than $1 \%$ of $\mathrm{F}_{2}$ progeny sensitive to nicosulfuron and rimsulfuron and less than $5 \%$ of $\mathrm{F}_{2}$ progeny sensitive to all three herbicides.

hybrids ranged from $0.1 \%$ to $20 \%$ and averaged $5 \%$ among the 12 trials. On average, tolerant hybrids were stunted $5 \%$ and $4 \%$ at 7 and $14 \mathrm{~d}$ after application of nicosulfuron, respectively.

Based on $t$ tests, injury was significantly $(P<0.06)$ greater for heterozygous hybrids than for homozygous-tolerant hybrids in 17 of 24 comparisons (Table 3). When the trial mean level of injury was above $4 \%$, heterozygous hybrids were injured significantly $(P<0.06)$ more than homozygous-tolerant hybrids in 15 of 16 comparisons. When the trial mean level of injury was below 4\%, heterozygous and homozygoustolerant hybrids were not significantly different in six of eight comparisons.

When mean levels of nicosulfuron injury to heterozygous hybrids were plotted against the trial mean levels of injury, the slope coefficient from the regression was 1.6 indicating that injury to heterozygous hybrids was $\approx 60 \%$ greater than average injury in a trial (Fig. 1A). When mean levels of injury to homozygous-tolerant hybrids were plotted against trial mean levels of injury, the slope coefficient from the regression was 0.7 indicating that injury to tolerant hybrids was $\approx 30 \%$ less than average injury in a trial. Slope coefficients for heterozy- gous and homozygous-tolerant hybrids were significantly different $(P<0.01)$ based on a $t$ test. When trial mean injury was above $4 \%$, the ratio of predicted injury to heterozygous hybrids compared with homozygous-tolerant hybrids ranged from 1.7 to 2.2; thus, nicosulfuron injured the group of heterozygous hybrids approximately twice as much as the group of homozygous-tolerant hybrids when conditions were conducive to injury.

COMPARISON OF FIELD RESPONSES TO FORAMSULFURON. Mean injury (percent stunting) at 7 or $14 \mathrm{~d}$ after application of foramsulfuron ranged from $2 \%$ to $31 \%$ and averaged $10.6 \%$ among the 12 trials (Table 4). On homozygous-sensitive hybrids, injury ranged from $3 \%$ to $100 \%$ and averaged $81 \%$. Fourteen days after application of foramsulfuron, homozygoussensitive hybrids were stunted $90 \%$ or more in 10 of 12 trials and were killed in five trials. Mean injury to heterozygous hybrids ranged from $0 \%$ to $37 \%$ and averaged $13 \%$ among the 12 trials. On average, heterozygous hybrids were stunted $15 \%$ and $11 \%$ at 7 and $14 \mathrm{~d}$ after application of foramsulfuron, respectively. Mean injury to homozygous-tolerant hybrids ranged from $0 \%$ to $26 \%$ and averaged $8 \%$ among the 12 trials. 
Table 2. Sweet corn hybrids classified as heterozygous for a gene-conditioning herbicide sensitivity based on 3:1 segregation of $F_{2}$ progeny for tolerant and sensitive responses to nicosulfuron, foramsulfuron, and mesotrione.

\begin{tabular}{|c|c|c|c|c|c|}
\hline \multirow{2}{*}{ Hybrid cultivar } & \multirow[b]{2}{*}{ Source ${ }^{z}$} & \multicolumn{2}{|c|}{ Plants (no.) } & \multirow[b]{2}{*}{ Sensitive $(\%)^{\mathrm{x}}$} & \multirow[b]{2}{*}{$P^{\mathrm{w}}$} \\
\hline & & Tolerant & Sensitive & & \\
\hline Argent & $\mathrm{Cr}$ & 120 & 53 & 31 & 0.09 \\
\hline Bojangles & $\mathrm{Cr}$ & 130 & 44 & 25 & 0.93 \\
\hline Bold $^{v}$ & Rog & 162 & 28 & 15 & 0.001 \\
\hline Brocade TSW & MM & 81 & 17 & 17 & 0.08 \\
\hline Chief Ouray & MM & 118 & 33 & 22 & 0.37 \\
\hline Coho & HM & 127 & 42 & 25 & 0.96 \\
\hline Colombus & $\mathrm{SnRv}$ & 82 & 24 & 23 & 0.57 \\
\hline CSUWP1-7 & $\mathrm{Cr}$ & 112 & 37 & 25 & 0.96 \\
\hline Delectable & $\mathrm{Cr}$ & 127 & 43 & 25 & 0.93 \\
\hline Empire & $\mathrm{SnRv}$ & 142 & 31 & 18 & 0.03 \\
\hline EX 08705640 & Sem & 148 & 39 & 21 & 0.19 \\
\hline EX $08705788^{v}$ & Sem & 125 & 23 & 16 & 0.008 \\
\hline EX 08755780 & Sem & 139 & 30 & 18 & 0.03 \\
\hline $\mathrm{GH} 2042^{\mathrm{v}}$ & Rog & 108 & 27 & 20 & 0.18 \\
\hline GH 2669 & Rog & 113 & 44 & 28 & 0.38 \\
\hline GH 4927 & $\operatorname{Rog}$ & 138 & 38 & 22 & 0.30 \\
\hline GH 6014 & Rog & 144 & 45 & 24 & 0.71 \\
\hline GH 6223 & Rog & 122 & 19 & 13 & 0.002 \\
\hline GH 8267 & Rog & 139 & 42 & 23 & 0.58 \\
\hline GSS 2914 & Rog & 73 & 17 & 19 & 0.18 \\
\hline Overland & $\operatorname{Rog}$ & 84 & 27 & 24 & 0.87 \\
\hline Polaris ${ }^{v}$ & $\mathrm{HM}$ & 101 & 28 & 22 & 0.39 \\
\hline Precious Gem & MM & 129 & 36 & 22 & 0.35 \\
\hline Punch & $\mathrm{SnRv}$ & 147 & 34 & 19 & 0.05 \\
\hline Ranger & HM & 127 & 33 & 21 & 0.20 \\
\hline SS Jubilee Plus & $\operatorname{Rog}$ & 57 & 19 & 25 & 1.00 \\
\hline Suregold & HM & 91 & 47 & 37 & 0.01 \\
\hline Turbo & HM & 117 & 47 & 29 & 0.28 \\
\hline UY 2830 OL & $\mathrm{SnRv}$ & 144 & 36 & 20 & 0.12 \\
\hline UY $2835 \mathrm{OL}$ & $\mathrm{SnRv}$ & 138 & 30 & 18 & 0.03 \\
\hline Welcome TSWv & MM & 95 & 16 & 14 & 0.01 \\
\hline Winstar & $\operatorname{Rog}$ & 126 & 39 & 24 & 0.69 \\
\hline
\end{tabular}

$\overline{{ }^{z} \mathrm{Cr}}=$ Crookham Co., Caldwell, ID; HM = Harris Moran Seed Co., Modesto, CA; MM = Mesa Maize, Olathe, CO; Rog = Syngenta Seeds Inc., Rogers Brands, Boise, ID; Sem = Seminis Inc., Oxnard, CA; SnRv = Snowy River Seeds, Orbost, Australia.

${ }^{y}$ Approximately $50 \mathrm{~F}_{2}$ progeny each evaluated for tolerant or sensitive responses to nicosulfuron, foramsulfuron, and mesotrione.

${ }^{x}$ Percentage of $F_{2}$ progeny sensitive to nicosulfuron, foramsulfuron, and mesotrione.

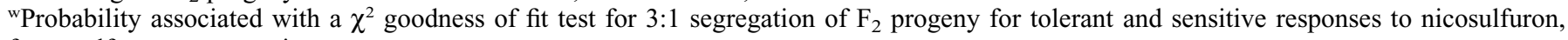
foramsulfuron, or mesotrione.

v'Hybrids with fewer than expected (i.e., 25\%) sensitive $F_{2}$ progeny for one of the three herbicides (see text). 
Table 3. Mean level of injury on sweet corn hybrids classified as homozygous-sensitive (SS), heterozygous (TS), or homozygous-tolerant (TT) after applications of nicosulfuron in 12 trials in 2005 and 2006.

\begin{tabular}{|c|c|c|c|c|c|c|c|}
\hline \multirow[b]{2}{*}{ Location of trial } & \multirow[b]{2}{*}{$\mathrm{Yr}$} & \multirow[b]{2}{*}{ Rating $(d)^{\mathrm{z}}$} & \multicolumn{4}{|c|}{ Mean level of injury $(\%)^{y}$} & \multirow[b]{2}{*}{$P^{\mathrm{v}}$} \\
\hline & & & Trial mean $^{\mathrm{x}}$ & $\mathrm{SS}^{\mathrm{w}}$ & $\mathrm{TS}^{\mathrm{w}}$ & $\mathrm{TT}^{\mathrm{w}}$ & \\
\hline Georgetown, DE & 2005 & 14 & 27.3 & 99 & 49.8 & 15.7 & $<0.0001$ \\
\hline Georgetown, DE & 2005 & 7 & 25.5 & 78 & 34.9 & 19.8 & $<0.0001$ \\
\hline LeRoy, NY & 2006 & 14 & 13.1 & 100 & 19.2 & 10.5 & 0.043 \\
\hline Georgetown, DE & 2006 & 14 & 11.3 & 100 & 16.7 & 8.9 & $<0.0001$ \\
\hline DeForest, WI & 2005 & 7 & 6.8 & 60 & 13.1 & 2.5 & $<0.0001$ \\
\hline Sun Prairie, WI & 2005 & 7 & 5.9 & 55 & 8.0 & 3.4 & $<0.0001$ \\
\hline Olathe, $\mathrm{CO}$ & 2005 & 7 & 5.7 & 68 & 5.8 & 3.9 & NS \\
\hline Stanton, MN & 2006 & 14 & 5.6 & 100 & 6.5 & 3.5 & 0.0350 \\
\hline DeForest, WI & 2005 & 14 & 5.5 & 93 & 8.5 & 1.8 & $<0.0001$ \\
\hline DeForest, WI & 2006 & 14 & 5.5 & 97 & 5.8 & 3.6 & 0.0690 \\
\hline Stanton, MN & 2006 & 7 & 5.4 & 85 & 8.1 & 2.9 & $<0.0001$ \\
\hline Caldwell, ID & 2005 & 14 & 3.0 & 60 & 2.7 & 1.6 & NS \\
\hline Caldwell, ID & 2005 & 7 & 3.0 & 25 & 2.9 & 2.4 & NS \\
\hline Nampa, ID & 2005 & 7 & 3.0 & 15 & 3.0 & 2.6 & NS \\
\hline Plainfield, WI & 2006 & 7 & 2.9 & 50 & 3.8 & 1.6 & 0.0140 \\
\hline Nampa, ID & 2005 & 14 & 2.6 & 55 & 1.8 & 1.4 & NS \\
\hline Plainfield, WI & 2006 & 14 & 2.1 & 99 & 1.9 & 0.5 & 0.0040 \\
\hline \multirow[t]{2}{*}{ Olathe, CO } & 2005 & 14 & 1.5 & 80 & 0 & 0.1 & NS \\
\hline & & Mean & 7.5 & 75.4 & 10.4 & 4.8 & \\
\hline
\end{tabular}

Injury ratings 7 or $14 \mathrm{~d}$ after the application of nicosulfuron.

${ }^{\mathrm{y}}$ Injury measured as stunting as a percentage of the height of nontreated controls.

${ }^{x}$ Trial mean injury weighted by number of hybrids in each of three classes. In 2005, $\mathrm{n}=2,34$, and 74 for SS, TS, and TT hybrids, respectively. In $2006, \mathrm{n}=1,24$, and 54 for SS, TS, and TT hybrids, respectively.

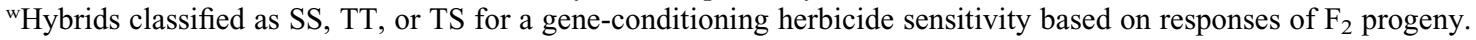

vProbability associated with a $t$ test comparison of means between TS and TT hybrids.

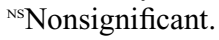

On average, homozygous-tolerant hybrids were stunted $10 \%$ and $6 \%$ at 7 and $14 \mathrm{~d}$ after application of foramsulfuron, respectively.

Based on $t$ tests, injury was significantly $(P<0.06)$ greater for heterozygous hybrids than for homozygous-tolerant hybrids in 19 of 24 comparisons (Table 4). When the trial mean level of injury was above $5 \%$, heterozygous hybrids were injured significantly $(P<0.06)$ more than homozygous-tolerant hybrids in 17 of 19 comparisons. When the trial mean level of injury was below 5\%, heterozygous and homozygous-tolerant hybrids were not significantly different in three of five comparisons.

When mean levels of foramsulfuron injury on heterozygous hybrids were plotted against the trial mean levels of injury, the slope coefficient from the regression was 1.3 indicating that injury to heterozygous hybrids was $\approx 30 \%$ greater than average injury in a trial (Fig. 1B). When mean levels of injury on homozygous-tolerant hybrids were plotted against trial mean levels of injury, the slope coefficient was 0.88 indicating that injury to homozygous-tolerant hybrids was $\approx 12 \%$ less than average injury in a trial. Slope coefficients for heterozygous and homozygous-tolerant hybrids were significantly different $(P<$ 0.01 ) based on a $t$ test. When trial mean injury was above $5 \%$, the ratio of predicted injury to heterozygous hybrids compared with homozygous-tolerant hybrids ranged from 1.5 to 1.8 ; thus, foramsulfuron injured the group of heterozygous hybrids $\approx 50 \%$ to $80 \%$ more than the group of homozygous-tolerant hybrids when conditions were conducive to injury.

Comparison of FiELd RESPONSES to Mesotrione. Mean injury (percent chlorotic leaf area) at 7 or $14 \mathrm{~d}$ after application of mesotrione ranged from $0 \%$ to $24 \%$ and averaged $4.7 \%$ among the 12 trials (Table 5). Injury ranged from $0 \%$ to $100 \%$ and averaged $33 \%$ on homozygous-sensitive hybrids. Seven and $14 \mathrm{~d}$ after application of mesotrione, homozygous-sensitive hybrids averaged $37 \%$ and $28 \%$ chlorotic leaf area, respectively. Mean injury to heterozygous hybrids ranged from $0 \%$ to $34 \%$ and averaged $7 \%$ among the 12 trials. On average, heterozygous hybrids had $10 \%$ and $5 \%$ chlorotic leaf area at 7 and $14 \mathrm{~d}$ after application of mesotrione, respectively. Mean injury to homozygous-tolerant hybrids ranged from $0 \%$ to $18 \%$ and averaged $3 \%$ among the 12 trials. On average, homozygous-tolerant hybrids had $4 \%$ and $2 \%$ chlorotic leaf area at 7 and $14 \mathrm{~d}$ after application of mesotrione, respectively.

Based on $t$ tests, injury was significantly $(P<0.05)$ greater to heterozygous hybrids than homozygous-tolerant hybrids in 16 of 23 comparisons (Table 5). When the trial mean level of injury was above $1 \%$, heterozygous hybrids were significantly $(P<0.05)$ more chlorotic than homozygous-tolerant hybrids in 15 of 17 comparisons. When the trial mean level of injury was 

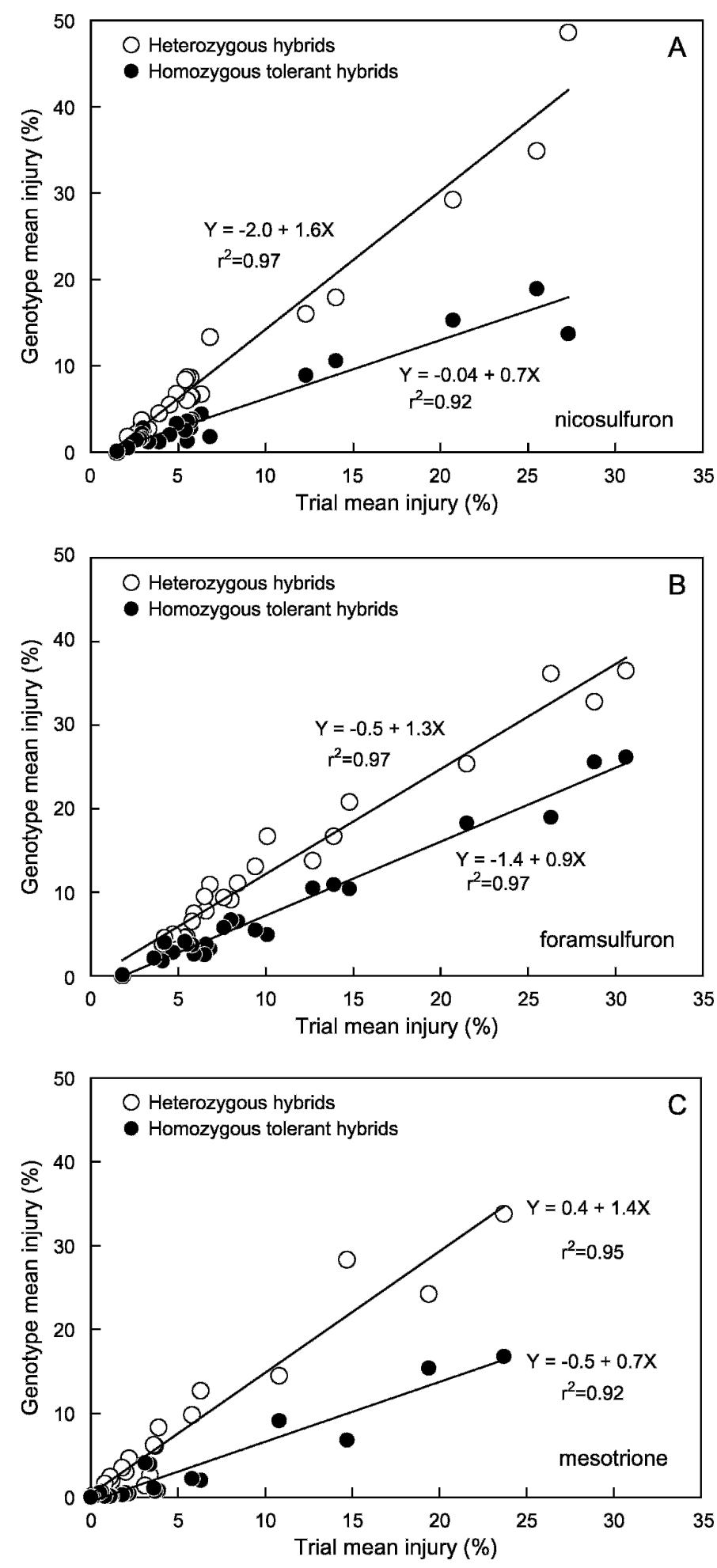

Fig. 1. Mean injury in 12 field trials in 2005 and 2006 at 7 and 14 d after application of (A) nicosulfuron, (B) foramsulfuron, or (C) mesotrione on sweet corn hybrids homozygous for alleles conditioning herbicide tolerance or hybrids heterozygous for alleles conditioning tolerance and sensitivity. Injury measured as percent stunting for nicosulfuron and foramsulfuron or percentage of chlorotic leaf area for mesotrione.

below $1 \%$, heterozygous and homozygous-tolerant hybrids were not significantly different in five of six comparisons.

When mean levels of mesotrione injury on heterozygous hybrids were plotted against the trial mean levels of injury, the slope coefficient from the regression was 1.4 indicating that injury to heterozygous hybrids was $\approx 40 \%$ greater than average injury in a trial (Fig. 1C). When mean levels of injury on homozygous-tolerant hybrids were plotted against trial mean levels of injury, the slope coefficient was 0.7 indicating that injury of homozygous-tolerant hybrids was $\approx 30 \%$ less than average injury in a trial. Slope coefficients for heterozygous and homozygous-tolerant hybrids were significantly different $(P<0.01)$ based on a $t$ test. When trial mean injury was above $4 \%$, the ratio of predicted injury to heterozygous hybrids compared with homozygous-tolerant hybrids ranged from 2.1 to 2.5 ; thus, mesotrione injured the group of heterozygous hybrids more than twice as much as the group of homozygoustolerant hybrids when conditions were conducive to injury.

\section{Discussion}

Sweet corn hybrids evaluated for tolerance to three P450metabolized postemergence herbicides in 12 trials in 2005 and 2006 differed substantially. The degree and type of injury also differed between herbicides with two different modes of action, ALS inhibitors and HPPD inhibitors. When the hybrids were characterized for alleles affecting herbicide metabolism, injury was associated with genotypic classes regardless of the mode of action or the presence of a herbicide safener. Two hybrids that were homozygous for an allele-conditioning herbicide sensitivity (i.e., a mutant CYP allele) were severely injured or killed by all three herbicides. Ninety-five hybrids that were homozygous for an allele-conditioning herbicide tolerance were uninjured or injured least by the three herbicides. Forty-seven hybrids that were heterozygous for alleles conditioning tolerance and sensitivity had responses to all three herbicides that were intermediate to homozygous-sensitive and homozygous-tolerant hybrids. When trial mean levels of injury after applications of mesotrione, nicosulfuron, and foramsulfuron were above minimal levels (i.e., greater than $1 \%$, greater than $4 \%$, and greater than $5 \%$, respectively), the response of the three genotypic classes of hybrids followed a consistent pattern. Homozygous-sensitive hybrids were injured most severely and often were killed by the ALS-inhibiting herbicides. The response of heterozygous hybrids to all three herbicides was more similar to homozygous-tolerant hybrids than to homozygous-sensitive hybrids; however, injury to heterozygous hybrids was $\approx 1.5$ to two times greater than injury to homozygous-tolerant hybrids.

Our observation that variation in levels of injury is associated with the presence of one or two nonfunctional CYP alleles is supported further by comparing hybrid responses from previous sweet corn-herbicide trials (Burton et al., 1994; Diebold et al., 2003; Masuinas et al., 2004; Morton and Harvey, 1992; O'Sullivan et al., 2002; Robinson et al., 1993; Stall and Bewick, 1992; Williams et al., 2005). The hybrids 'Merit', 'Del Monte 20-38', and 'Shogun' often have been identified as sensitive to or intolerant of specific, P450-metabolized herbicides. In this study, "Merit" was classified as homozygoussensitive based on sensitive responses of all $\mathrm{F}_{2}$ progeny. In a related study (Pataky et al., unpublished data), these three hybrids also were classified as homozygous for CYP alleles conditioning sensitivity. Other hybrids in previous evaluations have been observed to have moderate levels of visible injury or yield reduction resulting from $\mathrm{P} 450$-metabolized herbicides, including the hybrids 'Calico Belle', 'Cupola', 'Jubilee', 
Table 4. Mean level of injury (\%) on sweet corn hybrids classified as homozygous-sensitive (SS), heterozygous (TS), or homozygous-tolerant (TT) after applications of foramsulfuron in 12 trials in 2005 and 2006.

\begin{tabular}{|c|c|c|c|c|c|c|c|}
\hline \multirow[b]{2}{*}{ Location of trial } & \multirow[b]{2}{*}{$\mathrm{Yr}$} & \multirow[b]{2}{*}{ Rating $(\mathrm{d})^{\mathrm{z}}$} & \multicolumn{4}{|c|}{ Mean level of injury $(\%)^{y}$} & \multirow[b]{2}{*}{$P^{\mathrm{v}}$} \\
\hline & & & Trial mean $^{\mathrm{x}}$ & $\mathrm{SS}^{\mathrm{w}}$ & $\mathrm{TS}^{\mathrm{w}}$ & $\mathrm{TT}^{\mathrm{w}}$ & \\
\hline Georgetown, DE & 2005 & 7 & 30.5 & 73 & 36.5 & 26.1 & $<0.0001$ \\
\hline Stanton, MN & 2006 & 7 & 28.6 & 97 & 32.2 & 25.7 & 0.0130 \\
\hline Georgetown, DE & 2005 & 14 & 26.2 & 95 & 36.2 & 18.9 & $<0.0001$ \\
\hline Georgetown, DE & 2006 & 7 & 21.8 & 90 & 26.5 & 18.2 & $<0.0001$ \\
\hline Stanton, MN & 2006 & 14 & 15.2 & 100 & 21.8 & 10.6 & $<0.0001$ \\
\hline Georgetown, DE & 2006 & 14 & 14.0 & 100 & 17.2 & 10.9 & $<0.0001$ \\
\hline LeRoy, NY & 2006 & 14 & 12.7 & 100 & 14.0 & 10.6 & NS \\
\hline DeForest, WI & 2005 & 7 & 10.1 & 68 & 16.2 & 5.9 & $<0.0001$ \\
\hline Sun Prairie, WI & 2005 & 7 & 9.4 & 78 & 12.9 & 6.2 & $<0.0001$ \\
\hline Caldwell, ID & 2005 & 7 & 8.2 & 33 & 8.8 & 6.8 & 0.0030 \\
\hline DeForest, WI & 2006 & 7 & 8.2 & 40 & 11.0 & 6.3 & 0.0020 \\
\hline Plainfield, WI & 2006 & 7 & 7.7 & 60 & 9.9 & 5.5 & 0.0240 \\
\hline DeForest, WI & 2006 & 14 & 6.8 & 97 & 11.2 & 3.1 & 0.0010 \\
\hline Plainfield, WI & 2005 & 7 & 6.6 & 83 & 7.8 & 3.8 & 0.0020 \\
\hline DeForest, WI & 2005 & 14 & 6.5 & 90 & 9.5 & 2.6 & $<0.0001$ \\
\hline Sun Prairie, WI & 2005 & 14 & 5.9 & 93 & 7.7 & 3.0 & $<0.0001$ \\
\hline LeRoy, NY & 2006 & 7 & 5.7 & 100 & 6.3 & 4.0 & 0.0470 \\
\hline Caldwell, ID & 2005 & 14 & 5.5 & 80 & 4.8 & 3.8 & 0.0580 \\
\hline Olathe, $\mathrm{CO}$ & 2005 & 7 & 5.3 & 65 & 4.6 & 4.1 & NS \\
\hline Plainfield, WI & 2006 & 14 & 4.8 & 100 & 5.3 & 2.8 & 0.0250 \\
\hline Plainfield, WI & 2005 & 14 & 4.1 & 93 & 3.6 & 1.8 & 0.0200 \\
\hline Nampa, ID & 2005 & 7 & 4.1 & 3 & 4.7 & 3.9 & NS \\
\hline Nampa, ID & 2005 & 14 & 3.6 & 87 & 2.1 & 2.2 & NS \\
\hline \multirow[t]{2}{*}{ Olathe, CO } & 2005 & 14 & 1.9 & 100 & 0 & 0.1 & NS \\
\hline & & Mean & 10.6 & 81 & 13 & 8 & \\
\hline
\end{tabular}

${ }^{\mathrm{z}}$ Injury ratings 7 or $14 \mathrm{~d}$ after the application of foramsulfuron.

${ }^{\mathrm{y}}$ Injury measured as stunting as a percentage of the height of nontreated controls.

${ }^{x}$ Trial mean injury weighted by number of hybrids in each of three classes. In 2005, $\mathrm{n}=2,34$, and 74 for SS, TS, and TT hybrids, respectively. In $2006, \mathrm{n}=1,24$, and 54 for SS, TS, and TT hybrids, respectively.

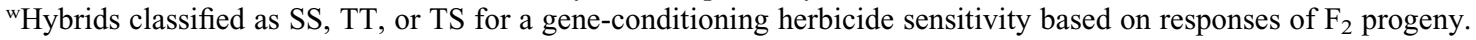

vProbability associated with a $t$ test comparison of means between TS and TT hybrids.

NS $=$ nonsignificant.

'Heritage', 'How Sweet It Is', 'Rival', 'Silver Xtra Sweet', 'Silverado', 'Snowbelle', 'SummerSweet 7201', 'SummerSweet 8701', 'Supersweet Jubilee', and 'Zenith'. Three hybrids among this group that were included in our studies (i.e., 'Jubilee', 'How Sweet It Is', and 'Supersweet Jubilee') were classified as heterozygous based on segregation of their $\mathrm{F}_{2}$ progeny. Similarly, the hybrid 'Crisp n Sweet 710', which had tolerant responses in previous trials, was classified as homozygous-tolerant in this study. Thus, the genetic grouping that explains variation among responses of hybrids to nicosulfuron, foramsulfuron, and mesotrione in these 12 field trials is corroborated by previous evaluations of sweet corn hybrid responses to these and related herbicides.

In some trials, none of the hybrids were substantially injured. Levels of injury on heterozygous and homozygous-tolerant hybrids were not significantly different in 19 of 71 comparisons. Sixteen of those 19 comparisons were from trials in Nampa, ID; Caldwell, ID; and Olathe, CO. In nine of these 16 situations, injury to the homozygous-sensitive hybrids was also substantially less than the mean level of injury for sensitive hybrids. Thus, low levels of injury tended to be associated with trials located in drier climates. Mesotrione has been shown to have greater foliar activity against certain weed species \{e.g., common waterhemp (Amaranthus rudis Sauer) and large crabgrass [Digitaria sanguinalis (L). Scop.]\} at high relative humidity and temperature (Johnson and Young, 2002). Possibly, injury to sweet corn from these herbicides also is more substantial under these environmental conditions.

Although the genotype of hybrids at a single locus explained a substantial amount of the variation in response of hybrids to nicosulfuron, foramsulfuron, and mesotrione, other factors had an effect on hybrid responses, especially to mesotrione. Some variation was observed within groups of homozygoustolerant and heterozygous hybrids. For example, injury ratings for a few homozygous-tolerant hybrids were consistently above the regression estimate of mean injury levels for homozygoustolerant hybrids indicating that those hybrids were consistently injured more than the average homozygous-tolerant hybrid (data not shown). Similarly, a few heterozygous hybrids were consistently injured less than the predicted value from the regression. Hybrids with consistent patterns of deviations from regression may be indicative of other factors that affect phenotype such as minor genes that do not distinctly affect phenotype among segregating $\mathrm{F}_{2}$ progeny as much as the CYP alleles but, nevertheless, noticeably affect levels of tolerance or sensitivity of hybrids. Thus, a hybrid with a homozygoustolerant genotype may not always be classified as having a tolerant phenotype and heterozygous hybrids may, in some 
Table 5. Mean level of injury on sweet corn hybrids classified as homozygous-sensitive (SS), heterozygous (TS), or homozygous-tolerant (TT) after applications of mesotrione in 12 trials in 2005 and 2006.

\begin{tabular}{|c|c|c|c|c|c|c|c|}
\hline \multirow[b]{2}{*}{ Location of trial } & \multirow[b]{2}{*}{$\mathrm{Yr}$} & \multirow[b]{2}{*}{ Rating $(d)^{z}$} & \multicolumn{4}{|c|}{ Mean level of injury $(\%)^{y}$} & \multirow[b]{2}{*}{$P^{\mathrm{v}}$} \\
\hline & & & Trial mean ${ }^{\mathrm{x}}$ & $\mathrm{SS}^{\mathrm{w}}$ & $\mathrm{TS}^{\mathrm{w}}$ & $\mathrm{TT}^{\mathrm{w}}$ & \\
\hline$\overline{\text { Georgetown, DE }}$ & 2005 & 7 & 23.5 & 73 & 33.3 & 17.9 & $<0.0001$ \\
\hline Georgetown, DE & 2005 & 14 & 19.5 & 70 & 24.2 & 16.0 & $<0.0001$ \\
\hline LeRoy, NY & 2006 & 7 & 14.7 & 90 & 29.6 & 6.9 & $<0.0001$ \\
\hline Georgetown, DE & 2006 & 7 & 10.8 & 5 & 15.1 & 8.9 & 0.0090 \\
\hline Stanton, MN & 2006 & 7 & 6.3 & 75 & 14.1 & 1.7 & $<0.0001$ \\
\hline LeRoy, NY & 2006 & 14 & 5.8 & 100 & 10.6 & 2.2 & $<0.0001$ \\
\hline Plainfield, WI & 2006 & 7 & 3.9 & 60 & 9.0 & 0.7 & 0.0010 \\
\hline Plainfield, WI & 2005 & 7 & 3.8 & 65 & 5.8 & 0.8 & $<0.0001$ \\
\hline DeForest, WI & 2005 & 7 & 3.6 & 43 & 5.8 & 1.2 & $<0.0001$ \\
\hline Nampa, ID & 2005 & 7 & 3.4 & 3 & 2.6 & 3.8 & NS \\
\hline Nampa, ID & 2005 & 14 & 3.0 & 0 & 1.5 & 4.0 & NS \\
\hline Sun Prairie, WI & 2005 & 7 & 2.2 & 20 & 4.7 & 0.4 & 0.0002 \\
\hline Stanton, MN & 2006 & 14 & 2.0 & 55 & 3.4 & 0.5 & 0.0010 \\
\hline DeForest, WI & 2005 & 14 & 1.7 & 20 & 3.2 & 0.3 & $<0.0001$ \\
\hline Plainfield, WI & 2005 & 14 & 1.4 & 28 & 1.7 & 0.2 & 0.0070 \\
\hline Sun Prairie, WI & 2005 & 14 & 1.1 & 12 & 2.2 & 0.1 & 0.0010 \\
\hline Plainfield, WI & 2006 & 14 & 0.8 & 15 & 1.7 & 0.1 & 0.0050 \\
\hline Caldwell, ID & 2005 & 14 & 0.7 & 0 & 0.6 & 0.7 & NS \\
\hline Caldwell, ID & 2005 & 7 & 0.7 & 3 & 0.5 & 0.5 & NS \\
\hline DeForest, WI & 2006 & 14 & 0.1 & 5 & 0 & 0 & NS \\
\hline DeForest, WI & 2006 & 7 & 0.1 & 5 & 0.2 & 0 & 0.0430 \\
\hline Olathe, CO & 2005 & 14 & 0 & 0 & 0 & 0 & NS \\
\hline \multirow[t]{2}{*}{ Olathe, CO } & 2005 & 7 & 0 & 0 & 0 & 0 & NS \\
\hline & & Mean & 5.2 & 35.5 & 7.9 & 3.1 & \\
\hline
\end{tabular}

${ }^{\mathrm{z}}$ Injury ratings 7 or $14 \mathrm{~d}$ after the application of mesotrione.

${ }^{y}$ Injury measured as percentage of leaf area bleached and chlorotic.

${ }^{x}$ Trial mean injury weighted by number of hybrids in each of three classes. In 2005, n =2, 34, and 74 for SS, TS, and TT hybrids, respectively. In $2006, \mathrm{n}=1,24$, and 54 for SS, TS, and TT hybrids, respectively.

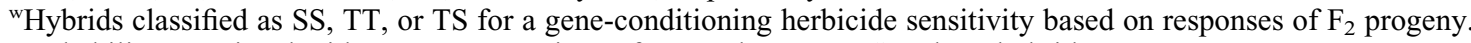

vProbability associated with a $t$ test comparison of means between TS and TT hybrids.

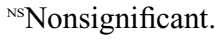

cases, be classified as having tolerant phenotypes (J.D. Bollman, unpublished data). Consequently, field evaluations may be necessary to confirm the phenotype of a hybrid even when the genotype at the Nsfl locus or other CYP loci is known.

Segregation of $F_{2}$ progeny of hybrids classified as heterozygous was not always consistent among the individual evaluations with nicosulfuron, foramsulfuron, and mesotrione, Most of the hybrids for which the probability from the $\chi^{2}$ goodness of fit test was low (i.e., $0.001<P<0.01$ ) were among this group. Additional evaluations of inbred parents and progeny of these hybrids may indicate that metabolism of a specific herbicide may be affected by more than one gene, which would be similar to the genetic basis for the metabolism of bentazon. Bradshaw et al. (1994) reported that tolerance to bentazon in field corn inbreds was conditioned by two independent, dominant genes (i.e., duplicate dominant epistasis), which Barrett et al. (1997) designated as Ben1 and Ben2. The Benl gene, which has been shown to be the same as the Nsfl gene (Williams et al., 2006), affected metabolism of bentazon, nicosulfuron, and imazethapyr, whereas the Ben2 gene was specific for bentazon (Barrett et al., 1997). Also, the activity of Ben1 was induced by an herbicide safener, naphthalic anhydride, whereas activity of Ben 2 was not. Bentazon metabolism also appears to be conditioned by two independent genes in $\mathrm{F}_{3: 5}$ families derived from a cross of sensitive and tolerant sweet corn inbreds, $\mathrm{Cr} 1$ and $\mathrm{Cr} 2$, respectively (Nordby et al., 2008).

Based on comparisons of predictions from regressions when mean levels of injury in a trial were $7 \%$ or greater, injury to heterozygous hybrids from nicosulfuron and mesotrione was 1.9 to 2.3 times greater than injury to homozygous-tolerant hybrids, whereas injury to heterozygous hybrids from foramsulfuron was only 1.5 to 1.7 times greater than injury to homozygous-tolerant hybrids. Although the overall level of injury from foramsulfuron was higher than the other two herbicides (i.e., grand mean levels of injury of $10.6 \%, 7.4 \%$, and $5.2 \%$ for foramsulfuron, nicosulfuron, and mesotrione, respectively), the smaller difference between levels of injury to heterozygous and homozygous-tolerant hybrids from foramsulfuron may have been the result of the inclusion of a herbicide safener, isoxadifen-ethyl, in the commercial formulation of foramsulfuron. Safeners have been shown to enhance the activity of P450 monooxygenases (Kreuz et al., 1996). Differential sensitivity in field corn to P450-metabolized herbicides has been associated with different rates of metabolism (Bunting et al., 2004; Eberlein et al., 1989; Hinz and Owen, 1996). Previously, Bunting et al. (2004) reported increased tolerance in field corn hybrids and increased metabolism of foramsulfuron when the herbicide was applied with the safener, isoxadifen-ethyl. If the normal rate of herbicide 
metabolism is slower in heterozygous sweet corn hybrids than in homozygous-tolerant sweet corn hybrids, enhancement of P450 activity from safeners may be of greater consequence in heterozygous hybrids, which would explain a more similar response of heterozygous and homozygous-tolerant hybrids to foramsulfuron.

Although environment and other factors affect crop injury from postemergence herbicides, the potential for injury and the level of injury from nicosulfuron, foramsulfuron, and mesotrione is substantially affected by alleles at a single locus, presumably the Nsf1/Ben1 locus or closely linked loci on the short arm of chromosome 5. Hybrids can be severely injured or killed after applications of nicosulfuron, foramsulfuron, or mesotrione if hybrids are homozygous for alleles that condition sensitivity to P450-metabolized herbicides. Use of these or other P450-metabolized herbicides on homozygous-sensitive hybrids is likely to result in unwanted, detrimental consequences. Under most conditions, heterozygous or homozygoustolerant hybrids are uninjured by these herbicides or levels of injury are relatively minor; however, under conditions conducive to crop injury, injury is greater to heterozygous hybrids than homozygous-tolerant hybrids. In the future, as new herbicides are screened for potential injury on sweet corn, and as recommended use rates are established for herbicides, inclusion of hybrids that are homozygous-tolerant, heterozygous, and homozygous-sensitive will provide a more complete assessment of the potential for crop injury. Similarly, by eliminating alleles that condition herbicide sensitivity such as the $n s f 1$ allele from sweet corn inbred lines, new hybrids will no longer be heterozygous or homozygous-sensitive, and the risk of injury to sweet corn from P450-metaboized herbicides will be reduced.

\section{Literature Cited}

Barrett, M. 1995. Metabolism of herbicides by cytochrome P450 in corn. Drug Metabol. Drug Interact. 12:299-315.

Barrett, M. 2000. The role of cytochrome P450 enzymes in herbicide metabolism, p. 25-37. In: Cobb, A.H. and R.C. Kirkwoods (eds.). Herbicides and their mechanisms of action. CRC Press, Boca Raton, FL.

Barrett, M., N. Polge, R. Baerg, R. Bradshaw, and C. Poneleit. 1997. Role of cytochrome P450 in herbicide metabolism and selectivity and multiple herbicide metabolizing cytochrome $\mathrm{P} 450$ activities in maize, p. 35-50. In: Hatzios, K. (ed.). Regulation of enzymatic systems detoxifying xenobiotics in plants. Kluwer Academic Publishers, Dordrecht, The Netherlands.

Bollman, J.D., C.M. Boerboom, and R.L. Becker. 2006. Efficacy and tolerance of HPPD-inhibiting herbicides in sweet corn. North Central Weed Sci. Soc. Abstr. 61:131 (abstr.).

Bollman, J.D., C.M. Boerboom, D.W. Morishita, M.J. VanGessel, R.R. Bellinder, G.L. Jordan, and W. Cooley. 2005. Sweet corn hybrid tolerance to mesotrione, nicosulfuron, and foramsulfuron. North Central Weed Sci. Soc. Abstr. 60:172 (abstr.).

Bradshaw, L.D., M. Barrett, and C.G. Poneleit. 1994. Inheritance of bentazon susceptibility in a corn (Zea mays) line. Weed Sci. 42:641647.

Bunting, J.A., C.L. Sprague, and D.E. Riechers. 2004. Physiological basis for tolerance of corn hybrids to foramsulfuron. Weed Sci. 52:711-717.

Burton, J.D., E.P. Maness, D.W. Monks, and R.R. Robinson. 1994. Sulfonylurea selectivity and safener activity in 'Landmark' and 'Merit' sweet corn. Pesticide Biochem. Physiol. 48:163-172.
Diebold, S., D. Robinson, J. Zandstra, J. O'Sullivan, and P.H. Sikkema. 2003. Sweet corn (Zea mays) cultivar sensitivity to AE F130360. Weed Technol. 17:127-132.

Eberlein, C.V., K.M. Rosow, J.L. Geadelmann, and S.J. Openshaw. 1989. Differential tolerance of corn genotypes to DPX-M6316. Weed Sci. 37:651-657.

Edenfield, M. and J. Allen. 2005. Sweet corn and popcorn tolerance to AE 0172747. North Central Weed Sci. Soc. Abstr. 60:91 (abstr.).

Fleming, A.A., P.A. Banks, and J.G. Legg. 1988. Differential responses of maize inbreds to bentazon and other herbicides. Can. J. Plant Sci. 68:982-987.

Green, J.M. and J.F. Ulrich. 1993. Response of corn (Zea mays L.) inbreds and hybrids to sulfonylurea herbicides. Weed Sci. 41:508516.

Hatzios, K.K. 1997. Regulation of xenobiotic degrading enzymes with herbicide safeners, p. 275-288. In: Hatzios, K.K. (ed.). Regulation of enzymatic systems detoxifying xenobiotics in plants. Kluwer Academic Publishers, Dordrecht, The Netherlands.

Hinz, J.R. and M.D.K. Owen. 1996. Nicosulfuron and primisulfuron selectivity in corn (Zea mays) and two annual grass weeds. Weed Sci. 44:219-223.

Johnson, B.C. and B.G. Young. 2002. Influence of temperature and relative humidity on the foliar activity of mesotrione. Weed Sci. 50:157-161.

Kang, M.S. 1993. Inheritance of susceptibility to nicosulfuron herbicide in maize. J. Hered. 84:216-217.

Kreuz, K., R. Tommasini, and E. Martinoia. 1996. Old enzymes for a new job: Herbicide detoxification in plants. Plant Physiol. 111:349353.

Masiunas, J., J. Pataky, C. Sprague, M. Williams, and L. Wax. 2004. Sweet corn cultivar tolerance to mesotrione. Weed Sci. Soc. Amer. Abstr. 44:58 (abstr.).

Morton, C.A. and R.G. Harvey. 1992. Sweet corn (Zea mays) hybrid tolerance to nicosulfuron. Weed Technol. 6:91-96.

Nordby, J.N., M.M. Williams, II, J.K. Pataky, D.E. Riechers, and J.D. Lutz. 2008. A common genetic basis in the sweet corn inbred $\mathrm{Cr} 1$ for cross-sensitivity to multiple cytochrome P450-metabolized herbicides. Weed Sci. 56:376-382.

O'Sullivan, J., J. Zandstra, and P. Sikkema. 2002. Sweet corn (Zea mays) cultivar sensitivity to mesotrione. Weed Technol. $16: 421-425$.

Pataky, J.K., J.N. Nordby, M.M. Williams, II, and D.E. Riechers. 2006. Inheritance of cross-sensitivity in sweet corn to herbicides applied post emergence. J. Amer. Soc. Hort. Sci. 131:744-751.

Ritchie, S.W., J.J. Hanway, and G.O. Benson. 1997. How a corn plant develops. Iowa State Univ. Sci. Technol. Coop. Ext. Serv. Spec. Rpt. No. 48.

Robinson, D.K., D.W. Monks, J.R. Schultheis, and A.D. Worsham. 1993. Sweet corn (Zea mays) cultivar tolerance to application timing of nicosulfuron. Weed Technol. 7:840-843.

Stall, W.M. and T.A. Bewick. 1992. Sweet corn cultivars respond differently to the herbicide nicosulfuron. HortScience 27:131-133.

Volenberg, D.S., M.M. Williams, II, J.K. Pataky, and D.E. Riechers. 2006. Responses of tolerant and sensitive sweet corn inbreds and near isogenic hybrids to postemergence herbicides with different modes of action. North Central Weed Sci. Soc. Abstr. 61:213 (abstr.).

Williams M.M., II and J.K. Pataky. 2008. Genetic basis of sensitivity in sweet corn to tembotrione. Weed Sci. 56:364-370.

Williams M.M., II, J.K. Pataky, J.N. Nordby, D.E. Riechers, C.L. Sprague, and J.B. Masiunas. 2005. Cross-sensitivity in sweet corn to nicosulfuron and mesotrione applied postemergence. HortScience 40:1801-1805.

Williams, M., S. Sowinski, T. Dam, and B.L. Li. 2006. Map-based cloning of the $n s f 1$ gene of maize. Prog. Abstr. 48th Maize Genet. Conf. p. 49 (abstr.) 